The Geographical Journal of Nepal, Vol. 7, 2009: 1-6

\title{
Human Settlements in High Altitude Region Nepal
}

\author{
Chhabi L Chidi \\ Assistant Lecturer \\ Central Department of Geography, Tribhuvan University \\ chh_chidi1963@yahoo.com
}

\begin{abstract}
Nepal has human settlements in high altitude areas above 3000 masl. Those areas of Himalayan region have extreme cold climate, rugged terrains, fragile geology and slow growing vegetation, which all create very low carrying capacity for human life. Despite these, the ethnic groups have been living in those areas for several hundred years. Yet, information on those settlements in Nepal is extremely lacking and therefore, our knowledge of understanding of planning and development needs of those areas is very poor. This paper is an attempt to identify the human settlements lying above $3000 \mathrm{~m}$ and analyse their distribution and size. Topographic maps of 1:50 000 have been used to find out location and size of those settlements. GIS and other software were used to extract and process required information. There are 1,282 high altitude settlements in Nepal with estimated households and population of 9,827 and 51,486 respectively. This paper analyses those settlements by altitudinal zones, major river basins from west to east, and size. The results would be helpful for further planning and development of those settlements with respect to the locally available natural resources.
\end{abstract}

\section{Introduction}

One of the crucial challenges in the planning and development of human settlements in Nepal is the lack of information base of those settlements particularly lying in the higher altitudes. Though the evolution of early human settlements in Nepal is believed to have taken place in the hills and mountains, knowledge about the locational patterns of human settlements and their factors and impacts on local environment and activities is limited for understanding the development of human settlements (Pradhan, 2009). In fact, human settlements have direct relations with the surrounding environmental resources available at their sites. Generally, it is argued that the mountain region comprising high altitude and extreme relief proves very difficult for human habitat and as a result, mountains have been mostly regarded as negative areas for any use (Clarke, 1990; Krentzmann, 1993). Over the last several hundred years, the human impact on mountain environment has been increased considerably. In the recent years, management of natural resources in the mountains has emerged as one of the most significant challenges to human understanding and organizational ability (Bandopadhyay, 1989).

In Nepal, few attempts have been made to study settlements in high altitudes (Hagen, 1998: Kuhle, 1990). Yet, our knowledge about the state of settlements particularly in higher 
altitudes in Nepal is extremely poor due to lack of data and information. So, this study attempts to analyse the settlements in terms of their spatial distribution and size and their factors in high altitudes of Nepal. This is an endeavour to complement to the existing gap of baseline data and characteristics related to high altitude settlements that may be useful for further planning and development of the settlements and natural resource uses in Nepal.

\section{Data and Methods}

This paper draws on data and information from the existing data sources such as topographic maps (1:50 000) of Survey Department (SD, 1995) and household and population of the Central Bureau of Statistics (CBS, 2001). In this paper, the high altitude settlements in Nepal are defined as those locating at $3000 \mathrm{~m}$ and over from the mean sea level. Location of settlements and their size were determined on the topographical maps. All the built-up points of the identified settlements were counted. The settlement clusters have been defined by the location, name and distribution pattern of their built ups using topography and drainage factors. Settlement size has been determined according to the number of housing built-ups. The households and population of each of the settlement clusters have been estimated based on the average household size of the respective Village Development Committee (VDC) provided by CBS. This was obtained by overlaying map layer of VDC boundary upon the layer of the defined settlement built-up units. The settlements have been categorized into six classes according to the number of housing built-ups they contain. The spatial distribution of settlement has also been analysed in terms of altitudinal zones by using 500 meter interval, such as $3000-3500 ; 3500-4000 \mathrm{~m}$ and so on. Further, the analysis of the settlements of high altitudes is made with reference to three broad drainage basins like the Karnali, Gandaki and Koshi from the west through the east covering entire country. Furthermore, the analysis is made by using tables, graphs and GIS and freehand software generated maps wherever feasible.

\section{Results and Analysis}

\section{Overview of High Altitude Settlements in Nepal}

Nepal's mountains include the Greater Himalayas, the Inner Himalayas and the Tibetan plateau with above 3000 masl (meter above sea level). The snowline begins at about $5000 \mathrm{~m}$ altitude. The total area of above $3000 \mathrm{~m}$ altitude covers 24.8 percent of the country's total area (HMG, 1980), of which 18.9 per cent lies in $3000-5000 \mathrm{~m}$ zone and 5.9 per cent above $5000 \mathrm{~m}$. One would expect that human habitation to grow is lower towards the north with its colder climate. Surprisingly this is not so. One can find that important villages of Manang lying at the altitude of 3800 masl. A number of fairly large sized villages are scattered in the altitudes of 3000 to 3 $600 \mathrm{~m}$ along the upper course of the Chhokang Chu river on the northern side of Manang mountains. In the Langu basin to the north of Dhaulagiri Himalaya, the Phopagaun lying at an altitude of 4300 masl is perhaps the highest permanent settlement anywhere in Asia where only barley and potato are grown (Hagen, 1998). These areas are very cold and winter snow falls below $3000 \mathrm{~m}$. Regeneration of vegetation is very slow and open alpine grassland is found above $4000 \mathrm{~m}$.

Some of the high altitude settlements are Okharpani ( $3100 \mathrm{~m})$ and Riusa villages (3 041m) of Mugu, Thakkhola, Thulokhola and Jaljala of Mustang (Gurung, 1980).The principal mountain peoples of Nepal are Bhote, Sherpa and Thakalis. Due to extreme cold climate most of their 
living areas are not favourable for crop production. In the lower southern river valleys, however few crops are grown during summer season. Some of them also operate trade business. They engage mostly in livestock farming due to availability of abundant open pasture lands. They have nomadic life shifting downward during the winter and upward during the summer in search of pasture fodder for their livestock and thus build temporary houses for living. So, the settlements above $3000 \mathrm{~m}$ are both permanent and semi permanent in nature (HMG, 1974). The seasonal settlements, being mainly single, double and small scattered settlements without field, or wood pasture settlements with modest requirement of space are situated on small level shelves in the upper valley, on ridges and crests above the tree limit, on the mountain saddle, or at the pass sites. Some of them are found on the dividing between the Thakkhola and the Thulokhola along the abandoned path from Lete to Lumpi which runs as high as 4500 $\mathrm{m}$. Likewise, the pass site and the level shelves of the Jaljala $(3500 \mathrm{~m})$ leading towards Dhorpatan are also being utilized by several single settlements (Kuhle, 1979). The high altitude settlements in Nepal can be analysed in terms of three broad drainage basins such as the Koshi watershed in the east, the Gandaki watershed in the centre and the Karnali watershed in the west (Fig. 1).

Figure 1: Broad Watershed Basins of High Altitude Settlements

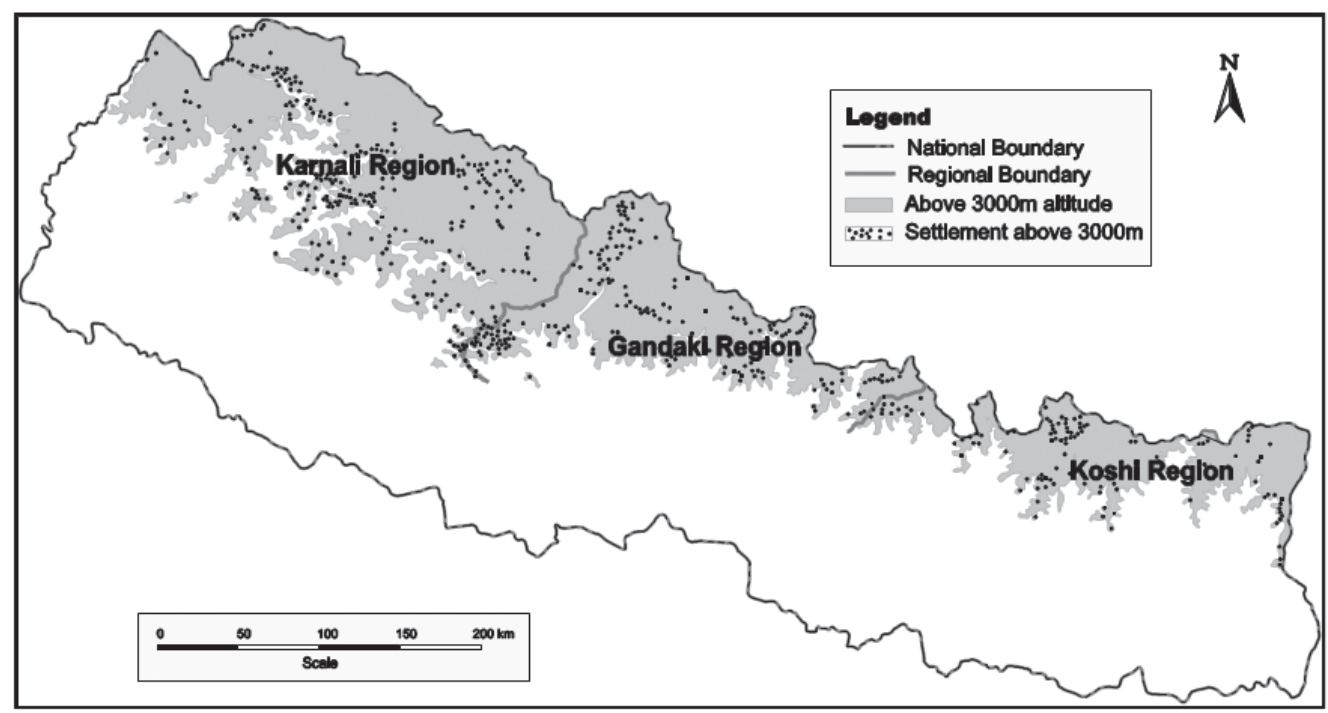

\section{Spatial Distribution of the High Altitude Settlements}

There are altogether 1,282 high altitude settlements in Nepal. The spatial distribution of these settlements is quite varied among the watershed regions and altitudinal zones. Of these, nearly 55 percent lie in the Karnali watershed, followed by the central drainage basin. The eastern watershed has the lowest number of high altitude settlements. Likewise, the altitudinal zone of $3000-3500$ has the largest number of high altitude settlements, with almost three-fifths of the total. There is a constant decrease in the number of high altitude settlements along with the increase of altitudinal zones. There are only three settlements above 5000 masl, but below 5500 masl; all they lie in the west drainage basin. In cumulative terms, the altitudinal zones 
comprising 3000 and above and ranging to below 4500 masl, share almost 96 percent of the total of high altitude settlements.

Table 1: Distribution of settlements by altitudinal zones

\begin{tabular}{|c|c|c|c|c|c|c|c|}
\hline \multirow{2}{*}{$\begin{array}{l}\text { Major river } \\
\text { basins }\end{array}$} & \multicolumn{5}{|c|}{ Number of settlements by altitudinal zones ('00 m) } & \multirow[t]{2}{*}{ Total } & \multirow[t]{2}{*}{ Percent } \\
\hline & $<35$ & $35-40$ & $40-45$ & $45-50$ & $>50$ & & \\
\hline Karnali & 474 & 133 & 79 & 12 & 3 & 701 & 54.68 \\
\hline Gandaki & 175 & 112 & 38 & 4 & 0 & 329 & 25.66 \\
\hline Koshi & 113 & 56 & 59 & 24 & 0 & 252 & 19.66 \\
\hline$\overline{\text { Total }}$ & 762 & 301 & 176 & 40 & 3 & 1282 & 100 \\
\hline Percent & 59.44 & 23.48 & 13.73 & 3.12 & 0.23 & 100 & \\
\hline
\end{tabular}

Source: Data were calculated from the topographic maps, Survey Department (1995)

The number of dwelling units in the identified settlements ranges from a single to 66 . According to the number of housing units, the high altitude settlements are classified into six groups (Table 2). Most of the settlement built-ups contain housing units of two and above up to 14. The settlement size with the number of housing units $2-4$ constitutes nearly 36 per cent, which can be said as 'small settlement', while those with 5-14 housing units share over 37 per cent and are termed as 'medium size settlement.' Large settlements with over 24 housing units, ranging up to 66 units make up only 3 per cent. The Koshi and the Karnali basins do have the largest size of settlements with above 48 housing units. Interestingly, there are settlements with only a single housing unit, which share slightly over 17 per cent. Such single house unit settlements resemble an isolated shrine at the top of the ridge, or some of them are cow-sheds widely scattered at the sites above $3500 \mathrm{~m}$. Table 2 shows that largest number of such single house settlements are in the Karnali basin, where there are 135 out of the 222 total single housing unit settlements. The distribution of these different sizes of the high altitude settlements correspond roughly with their number of the three drainage basins.

Table 2: Distribution of housing units by class

\begin{tabular}{|c|c|c|c|c|c|c|c|}
\hline \multirow{2}{*}{$\begin{array}{l}\text { Major river } \\
\text { basins }\end{array}$} & \multicolumn{6}{|c|}{ Number of housing units } & \multirow[t]{2}{*}{ Total } \\
\hline & 1 & $2-4$ & $5-14$ & $15-24$ & $25-48$ & $49-66$ & \\
\hline Karnali & 135 & 233 & 274 & 46 & 11 & 2 & 701 \\
\hline Gandaki & 48 & 118 & 120 & 28 & 15 & 0 & 329 \\
\hline Koshi & 39 & 109 & 85 & 9 & 7 & 3 & 252 \\
\hline$\overline{\text { Total }}$ & 222 & 460 & 479 & 83 & 33 & 5 & 1282 \\
\hline Percent & 17.32 & 35.88 & 37.36 & 6.47 & 2.57 & 0.39 & 100 \\
\hline
\end{tabular}

\section{Distribution of Different Sized Settlements by Altitudinal Zones}

Table 3 exhibits that all five largest settlements with above 48 housing units lie below 4500 masl; of which 3 fall below 3500 masl. Likewise, the largest number of housing units of all sizes lie in the altitudinal zones of $3000-3500$ masl and then the number constantly decreases, as the altitude increases. Thus, the table 3 information also justifies that the altitudinal zones, i.e. $3000-3500$ and $3500-4000$ are the most favourable for human habitation. These zones fall far below the permanent snow line. Another relatively better zone for human settlement is the altitudinal zone of $4000-45000$ masl. Just below the snow line zone, i.e. $4500-5000$ masl, the number of settlements share only slightly over 3 percent of the total high altitude settlements. 
Those settlements lying below 4000 masl can be related to the availability of resources for economic and social activities. Available documents indicate that the livelihood of the peoples of this region is associated with the activities based on grasslands, herbal collection and summer cropping. Although the daily life of the inhabitants is extremely difficult throughout the year due to extreme cold, some of the household members do not leave their homes even during the harsh winter. So, some of the settlements are not completely human less. Most of the villagers have settlements at two places for seasonal shifting with their livestock. Some of the high altitude settlements of upper Dolpa, Humla and Mustang have no connection with southern settlements for six and more months of winter season. Those settlements become isolated with the other parts of the country during that period (HMG, 1974). However, these relationships can be verified only if land use information or resource mapping is available.

Table 3: Distribution of housing units by altitudinal classes

\begin{tabular}{|c|c|c|c|c|c|c|c|c|}
\hline \multirow{2}{*}{$\begin{array}{l}\text { Altitudinal } \\
\text { zones (m) }\end{array}$} & \multicolumn{6}{|c|}{ Number of housing units } & \multirow[t]{2}{*}{ Total } & \multirow[t]{2}{*}{ Percent } \\
\hline & 1 & $2-4$ & $5-14$ & $15-24$ & $25-48$ & $>48$ & & \\
\hline $3000-3500$ & 141 & 265 & 284 & 53 & 16 & 3 & 762 & 59.44 \\
\hline $3500-4000$ & 48 & 111 & 107 & 20 & 14 & 1 & 301 & 23.48 \\
\hline $4000-4500$ & 21 & 62 & 80 & 10 & 2 & 1 & 176 & 13.73 \\
\hline $4500-5000$ & 10 & 21 & 8 & 0 & 1 & 0 & 40 & 3.12 \\
\hline $5000-5500$ & 2 & 1 & 0 & 0 & 0 & 0 & 3 & 0.23 \\
\hline Total222 & 460 & 479 & 83 & 33 & 5 & 1282 & 100.00 & \\
\hline
\end{tabular}

Source: Data were calculated from topographic map, Survey Department (1995)

\section{Household and Population of the High Altitude Settlements}

As noted above, there are 1,282 high altitude settlements located between 3000 and below 5 500 masl. Based on the defined built ups of those settlements, it is estimated that they possess 9,827 households, with their 51,486 population. The regional distribution of the household among the river basins is 5,275, 3,092 and 1,461 in the Karnali, the Gandaki and the Koshi respectively. Likewise, the distribution of population is $29,490,14,680$ and 7,316 for those three river basins accordingly (Table 4).

On average, the household number for each high altitude settlement is 7.67 and population size is 40.2. The number of average households is larger in the high altitude settlements of the Gandaki basin than those of the Karnali and Koshi basins (Table 4). The average village size in terms of population is also larger in the Gandaki basin than that of other two basins. In terms of both average household number and population size, the high altitude villages of the Koshi basin are the smallest.

Table 4: Estimated households and population size of high altitude settlements

\begin{tabular}{|c|c|c|c|c|c|}
\hline \multirow[t]{2}{*}{ Riverbasins } & \multirow[t]{2}{*}{ Housing units } & \multicolumn{2}{|c|}{ Household size } & \multicolumn{2}{|c|}{ Population size } \\
\hline & & Number & Average & Number & Average \\
\hline Karnali & 701 & 5,275 & 7.52 & 29,490 & 42.07 \\
\hline Gandaki & 329 & 3,092 & 9.40 & 14,680 & 44.62 \\
\hline Koshi & 252 & 1,461 & 5.80 & 7,316 & 29.03 \\
\hline Total/average & 1282 & 9,828 & 7.67 & 51,486 & 40.16 \\
\hline
\end{tabular}


The Geographical Journal of Nepal

Vol. 7

\section{Conclusion}

There are 1,282 high altitude settlements with above 3000 masl in Nepal. They are both permanent and semi permanent. The size of the settlements defined in terms of housing builtup units ranges from a single house settlement to as large as 66 housing units. As analysed the spatial distribution of those settlements by broad river basins, nearly sixty percent of the total settlements are found in the Karnali basin, which is obvious due to its larger high altitude area than other two river basins like the Gandaki and the Koshi. The Koshi basin has the lowest number of the settlements. The number and the size of the settlements are found constantly decreased with increasing altitude. Majority of those settlements are found at the altitudinal zones ranging from 3000 to 4500 masl. Likewise, the settlements having $5-14$ housing units are the largest in number, followed by the settlements with 2-4 housing units. The first one can be said as 'medium size village', whereas the latter are known as 'small village settlement.' There are however five settlements with containing above 48 housing units, which can be called as largest settlement. Those settlements with a single housing built-up unit are either isolated built-up structure along the main trail, or shrines at the top of the ridge or cattle-sheds. All these settlements are estimated to have 9,827 households and 51,486 population size.

Those high altitude settlements with their households or populations are only active in terms of economic viewpoint during the short summer season, while they are useless area during the harsh long winter season. In other words, majority of them are seasonally moved to the warmer areas. Due to extreme cold climate and rugged terrain, cultivation of crops is limited, but however livestock raising is the principal activity because of abundantly available grazing pasture. Carrying capacity of the existing grazing land, with virtually no practice of cultivation of fodder grasses is of great significance for future research. Likewise, study of land use and resource mapping with respect to area, human population and livestock population would be of great help for further planning and development of settlements in such high altitude zones of Nepal.

\section{References}

Bandyopadhyaya, J (1989), Natural resource management in the mountain environment. ICIMOD Occasional Paper. No 14. International Centre for Integrated Mountain Development.

Clarke, J I (1990), Mountain and man: an overview. In: Ahamad, A (ed.), Mountain Population Pressure. New Delhi: Vikas Publishing House Pvt. Ltd.

Gurung, H (1980), Vignettes of Nepal. Kathmandu: Sajha Prakashan.

Hagen, T (1998), Toni Hagen's Nepal: the Kingdom in the Himalaya. Lalitpur: Himal Books.

HMG (1974), Mechi Dekhi Mahakali (Parts I, II, III and IV). Kathmandu: His Majesty's Government of Nepal.

HMG (1980), Nepal Atlas of Economic Development. Kathmandu: His Majesty's Government of Nepal.

Kreutzmann, H (1993), Development trends in high mountain regions of the Indian subcontinent: a review. In: Hohuholz, J H, Mensching, $\mathrm{H}$ and Bittner, A (eds.), Applied Geography and Development: A Biannual Collection of Recent German Contributors. Vol 2. Germany: Institut Fur Wissenschaftliche Zusammenarbeit.

Kuhle, M (1979), Settlement on the Southern Slope of the Dhaula-Himal. Kathmandu: Nepal Research Centre.

Pradhan, P K (2009), Quantitative methods in geographic research. In: Pradhan, P K (ed.), Geographic Research Methods Handbook. Kathmandu: Central Department of Geography, Tribhuvan University. 